\section{Infra-red Spectrum and Germanium Co-ordina- tion in some High-pressure Meta-Germanates}

THE occurrence of high-pressure transformations in metagermanates, and their structural invəstigation by X-ray methods, have been reported recently by one of us (A. E. R.) ${ }^{1}$. An infra-red investigation of some of these new phases has now been earried out as a further check of the structural changes induced by pressure.

A schomatic diagram of the infra-red spectra is given in Fig. 1, which allows an easy comparison of tho patterns given by the 'common' and high-pressure (HP) forms of $\mathrm{MgGeO}_{3}, \mathrm{CaGeO}_{3}$ and $\mathrm{CdGeO}_{3}$.

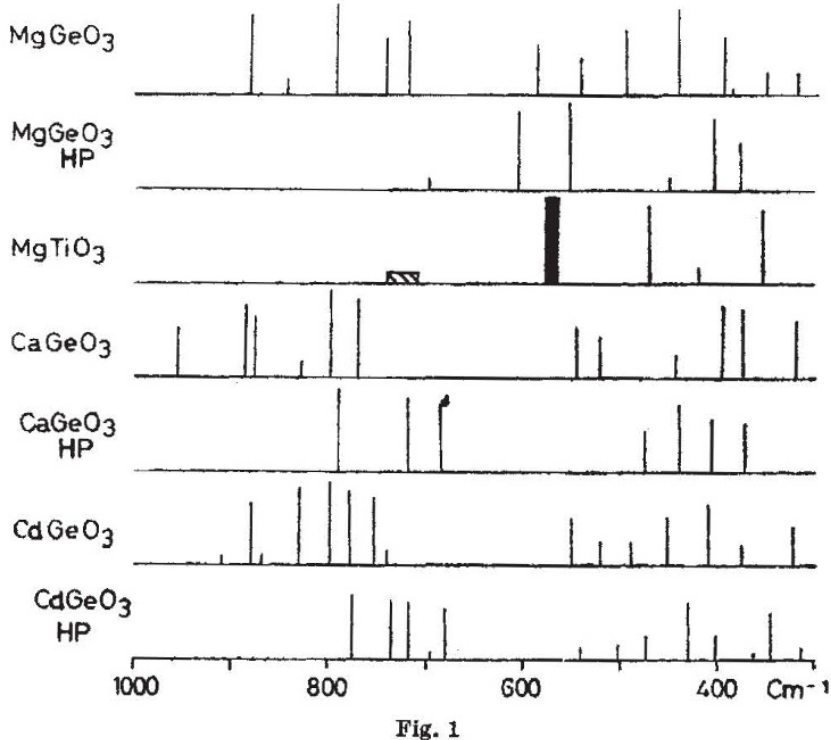

For each of these substances, the most striking difference between the infra-red spectra of the common and bighpressure forms is the shift towards the low frequencies experienced by the bands related to the Ge-O stretching vibrations. This shift may be explained by 2 types of structural changes: either a change of co-ordination of germanium, or a change in the 'linking mode' of the $\mathrm{GeO}$ tetrahedra.

(a) Change of co-ordination of germanium. The influence of the cation co-ordination number on the cation-oxygen vibrational frequencios has now been obsorved for a number of cations ${ }^{2}$. The characteristic frequency range, which is $900-700 \mathrm{~cm}^{-1}$ for $\mathrm{GeO}$ totrahedra, falls down to $650 \mathrm{~cm}^{-1}$ and bolow for $\mathrm{GeO}_{6}$ octahodra. This drop in frequency is well illustrated by the common and highpressure form of $\mathrm{MgGeO}_{3}$ (pyroxene and ilmenite structure respectively). The spoctrum of $\mathrm{MgTiO}_{3}$ (which also has the ilmenite structure) is given for the purpose of comparison: it should bo pointed out that the $\mathrm{GeO}_{6}$ and $\mathrm{TiO}_{6}$ stretching frequencies are very similar (near 600-550 $\mathrm{cm}^{-1}$ ) in these isomorphous compounds. This similarity in the stretehing frequencies of $\mathrm{Go}-\mathrm{O}$ and $\mathrm{Ti}-\mathrm{O}$ bonds has alroady bcen noticed for both tetrahedral $\left(\mathrm{Ba}_{2} \mathrm{GeO}_{4} \text { and } \mathrm{Ba}_{2} \mathrm{TiO}_{4}\right)^{3}$ and octahedral $\left(\mathrm{LiCrGeO}_{4} \text { and } \mathrm{LiCrTiO}_{4}\right)^{4}$ co-ordinations of germanium and titanium.

(b) Change in the 'linking mode' of the $\mathrm{GeO}_{4}$ tetrahedra. The high-pressure forms of $\mathrm{CaGeO}_{3}$ and $\mathrm{CdGeO}_{3}$ exhibit strong bands in the $800-700 \mathrm{~cm}^{-1}$ region; this clearly proves that $\mathrm{GeO}_{4}$ tetrahodra are still present in these structures. In such a case, the frequency shift is related to a transformation from a polygermanate (condensed $\mathrm{GeO}_{4}$ tetrahedra) to an orthogermanate structuro ('isolated" $\mathrm{GeO}_{4}$ tetrahedra). This is in agreement with the X-ray powder diagrams of these high-pressure phases, which may be interpreted on the basis of a garnet structure $\theta^{5}$, the eation distribution on the different sites being $\mathrm{Ca}_{3}$ vIII
[CaGe] ${ }^{\mathrm{VI}} \mathrm{Ge}_{3} \mathrm{IV} \mathrm{O}_{12}$. No information is available about the infra-red frequencies of isolated $\mathrm{GeO}_{6}$ octahedra; but, after a rough estimation, they should absorb noar or below $500 \mathrm{~cm}^{-1}$ (rof. 2). The high-pressure phases of $\mathrm{CaGeO}_{3}$ and $\mathrm{CdGeO}_{3}$ exhibit a series of bands in this region, but thoro is actually no definite assignment of these bands, bocause 2 types of vibrational modes (namely, tho bending frequoncy of $\mathrm{GeO}_{4}$ tetrahedra, and the strotching frequency of $\mathrm{GOO}_{6}$ octahedra) are represented in this spectral rango. Further work is noeded to settle this point.

\section{Dopartment of General Chemistry,} University of Liège.

Department of Geophysics,

Australian National University, Canberra.

1 Ringwood, A. E., Nature, 196, 883 (1962).

'Tarte, P., Silicates Industriels, 28, 352 (1963).

s Tarte, P., Nature, 191, 1002 (1961).

${ }^{4}$ Tarte, P., Acta Cryst., 16, 228 (1963).

${ }^{3}$ Ringwood, A. E., J. Geophys. Res., 68, 4601 (1963).

$$
\text { P. Tarte }
$$

\section{A. E. Ringwood}

\section{BIOPHYSICS}

\section{Some Physical Properties of Chick Interferon}

DESPITE much intensive investigation on the propertics of interferon produced in chick tissue, both the molecular weight and the iso-electric point of the active molecule continuo to be a source of controversy. Thus Burke ${ }^{1}$ reported a value of 63,000 for the molecular weight of interferon produced in the chorioallantoic membrane of fertile hens' eggs and suggested that the isoelectric point was between $p H \quad 4 \cdot 5$ and $5 \cdot 0$. Other investigators ${ }^{2-4}$, however, have describod interferon purified from chick material as having a molocular weight ranging from 80,000 to $20-34,000$. Recently, Rotem and Charlwood ${ }^{5}$ on the basis of tho sedimentation rates of unrefined interferons in density gradients suggested that the molecular weight of ehick interferon might be as low as 13,00025,000. In further contrast to Burke's findings, interferon has been described by two groups of workers as being a basic protein ${ }^{3,6}$.

In this communication, an account is given of the behaviour of chick interferon on columns of 'Sephadex $G-100^{\prime}$ and of the electrophoretic behaviour of interferon in starch gels.

The starting material for these investigations was obtained by inoculating 11-day-old fertilo hens' eggs with influonza virus ( $B /$ England) and withdrawing the allantoic fluid aftor $48 \mathrm{~h}$ at $38.3^{\circ}$. After centrifugation (25 min at $53,620 \mathrm{~g}$ ) residual virus in the supernatant was inactivated by treatment at $p \mathrm{H} 2$ overnight. After readjustment to $p H$. $7 \cdot 0$, the starting fluid at a concentration of $1 / 50$ gave 50 per cent reduction in plaque count ${ }^{7}$ compared with unprotected controls in a system in which monolayers of primary chick embryo cells were infected with Semliki Forest virus. Preliminary concentration of interforon was achieved by precipitation by means of ammonium sulphate at 0.73 saturation. After dissolving the precipitate in water and dialysing to remove ammonium sulphate, the volume of the interferon solution was made to one-fifth of that of the original allantoic fluid.

A column $(90 \times 5.4 \mathrm{~cm})$ of 'Sephadex $6-100$ ' packed in phosphate buffer ${ }^{8}$ at $p H 7 \cdot 7, \mu=0 \cdot 1$, was calibrated using a number of protein 'markers' of known molecular woight (bovine serum albumin, chymotrypsin and ribonuclease), thus establishing a rolationship between retention volume and molecular weight.

The interferon solution concentrated as already de. scribed when fractionated on the column gave rise to seven distinct groups of compounds (Fig. 1). On assaying the 